\title{
Anti-plasmodial action of de-novo-designed, cationic, lysine-branched, amphipathic, helical peptides
}

\author{
Naveen K Kaushik*, Jyotsna Sharma, Dinkar Sahal \\ From Challenges in malaria research \\ Basel, Switzerland. 10-12 October 2012
}

\section{Background}

A lack of vaccine and rampant drug resistance demands new anti-malarials under such circumstances antibiotic peptides may offer a novel approach to tackle the parasite.

\section{Methods}

In vitro blood stage anti-plasmodial properties of several de novo-designed, chemically synthesized, cationic, amphipathic, helical, antibiotic peptides were examined against Plasmodium falciparum using SYBR Green assay. Mechanistic details of anti-plasmodial action were examined by optical/fluorescence microscopy and FACS analysis.

\section{Results}

Unlike the monomeric decapeptides \{(Ac-GXRKXH$\left.\left.\mathrm{KXWA}-\mathrm{NH}_{2}\right)(\mathrm{X}=\mathrm{F}, \Delta \mathrm{F})\left(\mathrm{Fm} \Delta \mathrm{Fm} \mathrm{IC} \mathrm{I}_{50}>100 \mu \mathrm{M}\right)\right\}$, the lysine-branched,dimeric versions showed far greater potency $\left\{\mathrm{IC}_{50}(\mu \mathrm{M}) \mathrm{Fd} 1.5, \Delta \mathrm{Fd} 1.39\right\}$. The more helical and proteolytically stable $\Delta \mathrm{Fd}$ was studied for mechanistic details. $\Delta \mathrm{Fq}$, a $\mathrm{K}-\mathrm{K}_{2}$ dendrimerof $\Delta \mathrm{Fm}$ and $(\Delta \mathrm{Fm})_{2}$ a linear dimer of $\Delta \mathrm{Fm}$ showed $\mathrm{IC}_{50}(\mu \mathrm{M})$ of 0.25 and 2.4 respectively. The healthy/infected red cell selectivity indices were $>35(\Delta \mathrm{Fd})$, $>20(\Delta \mathrm{Fm})_{2}$ and $10(\Delta \mathrm{Fq})$. FITC- $\Delta \mathrm{Fd}$ showed rapid and selective accumulation in parasitized red cells. Overlaying DAPI and FITC florescence suggested that $\triangle \mathrm{Fd}$ binds DNA. Trophozoites and schizonts incubated with $\Delta \mathrm{Fd}(2.5 \mu \mathrm{M})$ egressed anomalously and Band-3 immunostaining revealed them not to be associated with RBC membrane. Prematurely egressed merozoites from peptide treated cultures were found to be invasion incompetent.

Malaria Research Group, International Centre for Genetic Engineering and Biotechnology, Aruna Asaf Ali Marg, New Delhi, 110067, India

\section{Conclusion}

Good selectivity (>35), good resistance index (1.1) and low cytotoxicity indicate the promise of $\Delta \mathrm{Fd}$ against malaria.

Published: 15 October 2012

doi:10.1186/1475-2875-11-S1-P55

Cite this article as: Kaushik et al.: Anti-plasmodial action of de-novodesigned, cationic, lysine-branched, amphipathic, helical peptides.

Malaria Journal 2012 11(Suppl 1):P55.
Submit your next manuscript to BioMed Central and take full advantage of:

- Convenient online submission

- Thorough peer review

- No space constraints or color figure charges

- Immediate publication on acceptance

- Inclusion in PubMed, CAS, Scopus and Google Scholar

- Research which is freely available for redistribution 